\title{
Divna Glumac
}

\section{Pasivna rečenica u nastavi japanskog jezika na početnom nivou i prevazilaženje problema njene upotrebe}

\author{
Izvorni znanstveni rad
}

Original scientific paper

UDK 811.521'367

https://doi.org/10.32728/tab.16.2019.6

\section{ABSTRAKT}

Specifičnost japanske pasivne rečenice je što osim predmeta i bića direktno obuhvaćenih radnjom u ulozi subjekta-pacijensa može biti i vlasnik objekta nad kojim je radnja izvršena, pa i lice koje nije obuhvaćeno glagolskom radnjom već indirektno trpi njen uticaj, najčešće kao smetnju. Tako pasiv obuhvata i značenja posesije i štete. U udžbenicima za početni nivo koji su se do sada koristili u nastavi na Filološkom fakultetu u Beogradu, pasiv u japanskom se objašnjava kroz prikaz strukture i izvođenje pasivne rečenice iz aktivne. Zaključak je da jedna situacija može biti opisana bilo aktivom bilo pasivom, ali ne daju se dalja objašnjenja za ovu prividnu jezičku neekonomičnost. Posledica je nerazumevanje i izostanak upotrebe pasivne rečenice na višim nivoima jezičke kompetencije. Uzrok ovome mogla bi biti interferencija maternjeg jezika, koji poseduje pasivnu strukturu, ali njena upotreba nije široko zastupljena. Drugi razlog bi mogao biti što je upotreba pasivne rečenice objašnjena na nivou rečenice. Otuda se javlja potreba da se ova struktura objasni na nivou diskursa, u okviru šire kategorije - glagolskog roda.

Cilj ovog istraživanja je da se, na primeru specijalnog časa, ispita koliko studenti razumeju upotrebu japanske pasivne rečenice kada se ona objasni s polazišta glagolskog roda, i koliko takav pristup može da pomogne u prevazilaženju problema interferencije maternjeg jezika, u upotrebi pasiva u japanskom kao i u prevođenju sa srpskog na japanski.

Osim objašnjenja o upotrebi pasivne rečenice, na času se ukazuje i na neke postulate teorije prevođenja. Zatim, studenti imaju zadatak da grupno diskutuju o upotrebi pasiva u ponuđenim primerima, a potom da samostalno, u pisanom obliku, u oba smera prevedu rečenice u kojima je upotrebljen pasiv na japanskom. Za vežbe prevođenja koristili smo reče- 
nice iz književnog korpusa. Prikupljene podatke u vidu pisanog prevoda nastavnik analizira, poredeći ih sa književnim prevodom.

Ključne reči: glagolski rod, japanski pasiv, direktni pasiv, indirektni pasiv, diskurs, subjekat, perspektivizacija, empatija, hijerarhija.

\section{UVOD}

U udžbenicima japanskog jezika za početni nivo koji su se do sada koristili u nastavi na Filološkom fakultetu u Beogradu, Nihongo shoho (1981) i Shokyū nihongo (Tokyo Gaikokugo Daigaku 1990), pasiv je predstavljen kroz strukture tipova pasivne rečenice, uz objašnjenje njihovih značenja $i$ ukazivanje na životne situacije u kojima se data struktura koristi. Akcenat se stavlja na odnos rečeničnih konstituenata pasivne i korelativne aktivne rečenice. Učenici mogu da zaključe da jedna situacija može da se iskaže i aktivom i pasivom, ali na temelju informacija iz udžbenika ne stiču dalja objašnjenja za ovakvu prividnu jezičku neekonomičnost. Ovo za posledicu ima izostanak upotrebe pasiva od strane učenika na višim nivoima jezičke kompetencije prilikom vežbi govorne ili pisane produkcije na japanskom, kao i primeri grešaka na ispitima, o čemu svedoče iskustva nastavnika.

Kao jedan od razloga za ovo mogla bi se navesti interferencija učenikovog maternjeg jezika, koji poznaje pasivnu rečenicu, ali je njena upotreba svedena ili nije rasprostranjena, kao što je slučaj sa srpskim. Kada je jednu situaciju moguće opisati i pasivnom i aktivnom rečenicom, suočen sa izborom između datih dveju mogućnosti, učenik će se lakše opredeliti za upotrebu aktiva nego pasiva. Drugi razlog mogao bi biti u tome što se upotreba pasiva u japanskom u udžbenicima za početni nivo objašnjava samo na nivou rečenice i ne uzimaju se u obzir širi kontekst i tok diskursa. I vežbe na koje se studenti upućuju u okviru gramatičko-prevodnog metoda, koji se dugo primenjivao u nastavi, svodile su se na prevođenje nepovezanih rečenica sa ciljnog jezika, japanskog, na maternji, srpski, i obrnuto. To je rezultiralo fokusiranjem studenta na samu gramatičku strukturu i težnjom da se ona prenese u maternji jezik, čak i kada to ne odgovara njegovim jezičkim navikama, što je suprotno pravilima prevođenja. Između dva tipološki različita jezika, kakvi su japanski i srpski, mehaničko prenošenje nije moguće zbog morfoloških, sintaksičkih i drugih razlika među njima. Ovo je naročito važno imati na umu kod književnog prevoda, koji „traži viši stepen ekvivalentnosti“ (Sibinović 1990: 138). Nekada se pasivna struktura može preneti u prevodu, kao u slučaju tzv. direktnog pasiva u primeru Watashi-wa sensē-ni homeraremashita (Tokyo Gaikokugo Daigaku 1990: 214) 'Ja sam pohvaljen od strane učitelja', ali je u srpskom ipak prirodnija upotreba aktiva nego pasiva ('Učitelj me je pohvalio'). 
I u obrnutom smeru, ukoliko u srpskom jeziku nije upotrebljen pasiv, a opisana situacija nalaže upotrebu pasiva u japanskom, kao na primer u slučaju tzv. pasiva smetnje, prevodeći sa srpskog na japanski, student neće prepoznati priliku za upotrebu pasiva, osim ako nije u pitanju neka od ograničenog broja specifičnih situacija, kao što su 'Sav sam pokisao', 'Umro mi je otac', i sl., koje u japanskom zahtevaju upotrebu pasiva, a koje su opisane u udžbenicima: Ame-ni furaremashita; Chichi-ni shinaremashita (Tokyo Gaikokugo Daigaku 1990: 215).

U naučnoj literaturi upravo se tok diskursa navodi kao jedan od faktora koji uslovljava upotrebu pasiva (Teramura 1982, Okutsu 1983, Murakami 1986). Otuda se ukazuje potreba da se navedene strukture i njihova upotreba objasne u okviru više kategorije, kategorije glagolskog roda. Kategorija glagolskog roda univerzalna je odlika jezika različitih tipova. Njome se obeležava odnos između učesnika događaja obuhvaćenih radnjom, a kao prototipični predstavnici uzimaju se aktiv i pasiv, koji stoje u odnosu opozicije. U japanskom jeziku glagolski rod se tumači principom perspektivizacije i tačke gledišta (Teramura 1982: 218; Okutsu 1983: 65; Murakami 1986: 8) Kategorija glagolskog roda u japanskom je, međutim, nešto složenija, i opoziciji aktiv-pasiv mora se dodati makar još jedan, a to je kauzativ. I u pasivnoj i u kauzativnoj rečenici menja se perspektiva u odnosu na aktivnu i vršilac radnje se izmešta sa pozicije subjekta na poziciju tzv. agentivne dopune.

Cilj ovog istraživanja je da se, na primeru specijalnog časa, ispita koliko studenti razumeju upotrebu japanske pasivne rečenice kada se ona objasni s polazišta glagolskog roda, i koliko takav pristup može da pomogne u prevazilaženju problema interferencije maternjeg jezika, u upotrebi pasiva u japanskom kao i u prevođenju sa srpskog na japanski. Rad je delom usmeren i na osvešćivanje problema kod nastavnika japanskog, koji možda nisu dovoljno svesni ovog problema u nastavi.

Osim objašnjenja o upotrebi pasivne rečenice, na času smo ukazali i na neke postulate teorije prevođenja. Studenti su potom imali zadatak da grupno diskutuju o upotrebi pasiva u ponuđenim primerima, a zatim da samostalno, u pisanom obliku, u oba smera prevedu rečenice u kojima je upotrebljen pasiv u japanskom. Za vežbe prevođenja koristili smo rečenice iz književnog korpusa. Prikupljene podatke u vidu pisanog prevoda nastavnik analizira, poredeći ih sa književnim prevodom.

U radu se primenjuje Hepburn transkripcija prilikom romanizacije japanskog teksta, dok se japanska imena u srpski prenose fonetskom transkripcijom, što je način propisan pravopisom srpskog jezika. 


\section{PASIV I GLAGOLSKI ROD - TEORIJSKI OKVIR}

U japanskom jeziku pasiv se izučava u okviru kategorije glagolskog roda. Glagolski rod se objašnjava promenom rečenične perspektive i definiše se pojmom „tačke gledišta“, tachiba (Suzuki 1972: 278; Okutsu 1984: 192; Teramura 1982: 218), shiten (Okutsu 1983: 65). Suzuki (1972: 278) određuje kategoriju glagolskog roda time da li će se na mesto subjekta odnosno objekta iskaza staviti vršilac ili predmet radnje, ili treće lice koje je u bilo kakvom odnosu s radnjom. Subjekat može da postane i treće lice koje nije direktno obuhvaćeno radnjom, dakle imenica koje nema u aktivnoj rečenici.

Aktivna rečenica o događaju saopštava sa tačke gledišta vršioca radnje, agensa, i postavlja ga na poziciju subjekta, dok pasivna rečenica na mesto subjekta stavlja onog na kome se radnja vrši (direktni objekat) ili onog prema kome je radnja usmerena (indirektni objekat). Kauzativ, opet, na poziciju subjekta uvodi onog koji samim događajem nije obuhvaćen, ali je inicijator ili kauzator događaja.

Ukoliko posmatramo aktivnu i pasivnu rečenicu koje opisuju isti događaj, uočićemo mehanizam poznat u mnogim jezicima, a to je da subjekat i objekat aktivne i pasivne rečenice zamenjuju mesta. Ovakav pasiv se naziva direktni, chokusetsu ukemi, a nasuprot njemu stoji indirektni pasiv, kansetsu ukemi (Teramura 1982: 215; Okutsu 1983: 68). Ovde treba imati na umu da se kvalifikacija „direktni“ odnosno „indirektni“ odnosi na to da li je entitet na mestu subjekta pasivne rečenice a u ulozi pacijensa direktno ili indirektno obuhvaćen radnjom glagola u osnovi, tj. da li je pacijens direktni trpilac radnje ili indirektno trpi efekat radnje izvršene nad nekim drugim entitetom. Indirektni pasiv na poziciji subjekta ima novouvedeni entitet koji nije postojao u rečenici aktiva kojom se opisuje događaj. Ovaj tip pasivne rečenice naziva se i „pasiv trećeg lica“, daisansha no ukemi (Suzuki 1972: 281; Murakami 1986: 83), a novouvedeni subjekat je tzv. „treće lice“ u odnosu na prvobitni događaj. Takav subjekat je uvek živo biće, a efekat radnje koji on trpi je negativan. Radnja se odvija nezavisno od lica na mestu subjekta indirektnog pasiva a njen stvarni efekat i ne mora da bude usmeren na njega, ali je subjekat tako doživljava. Za razliku od direktnog pasiva, u rečenici indirektnog pasiva glagol u osnovi može biti i neprelazan. Indirektnom pasivu je slična kauzativna rečenica. Ona nastaje po istom principu, tako što se na mesto subjekta dovodi entitet (lice ili predmet) u ulozi kauzatora, koji nije postojao u prvobitnoj aktivnoj rečenici a od koga radnja ili podsticaj za vršenje radnje kreće. Sličnost između kauzativa i rečenice indirektnog pasiva je i u postojanju dejstvenog odnosa između subjekta i radnje, jedino što se razlikuje smer dejstva: kod indirektnog pasiva dejstvo ide od radnje ka subjektu, dok je kod kauzativa dejstvo usmereno od subjekta ka izazvanoj radnji. Sličnost postoji i u prisustvu subjektivnog doživljaja. Naime, kod jednog tipa kauzativne rečenice, lice na mestu subjekta sebi pripisuje odgovornost ili krivicu za to 
što je izazvalo neku radnju ili nije sprečilo da se ona izvrši. U primerima koje nude udžbenici uočen je i tip pasivne rečenice koji izražava odnos posesije između entiteta na poziciji subjekta i direktnog objekta:

\section{わたしはどろぼうにさいふをぬすまれました。(Nihongo shoho 1981: 265)}

Watashi-wa dorobō-ni saifu-wo nusumaremashita.

Lopov mi je ukrao novčanik.

弟は兄に顔をなぐられました。(Tokyo Gaikokugo Daigaku 1990: 214)

Otōto-wa ani-ni kao-wo naguraremashita.

Mlađi brat je udaren u lice od strane starijeg.

U pasivnoj rečenici, predmet posesije nad kojim je izvršena radnja (saifu 'novčanik' / kao 'lice') ostao je na mestu objekta, dok je posesor stavljen na poziciju subjekta, kao onaj ko posredno trpi uticaj radnje time što je radnjom obuhvaćen neki njegov deo, bilo da je deo otuđiva ili neotuđiva svojina.

Primećujemo da se u japanskom jeziku određene situacije mogu izraziti i aktivom i pasivom, a koji će se oblik upotrebiti zavisi od stava, interesa i brige govornika. U tom smislu i Teramura definiše pasiv kao „izraz kojim se opisuje situacija kada subjekat radnje dejstvuje na nekoga ili nešto što nije on sam, pri čemu se za glavnu ulogu ne uzima onaj koji pokreće radnju već onaj koji radnju prima, odnosno prema kome je radnja usmerena" (Teramura 1982: 246). Jedan od razloga upotrebe pasivne rečenice, dakle, jeste dodeljivanje glavne uloge pacijensu radnje, odnosno saopštavanje događaja iz perspektive pacijensa, dok je agens proteran sa pozicije subjekta i dobija ulogu dopune. Zamena uloga između strana obuhvaćenih radnjom, prema Teramuri, odlika je direktnog pasiva, koji ima odgovarajući aktivni izraz, dok indirektni pasiv „opisuje scenu gde neko ko stoji izvan scene i posmatra je sa strane prima uticaj usled događaja koji se odigrava na sceni“" (Teramura 1982: 246). Uticaj koji subjekat trpi usled odigrane radnje je najčešće ugrožavajući. Učešće subjekta rečenice indirektnog pasiva u događaju opisanom glavnim glagolom je pasivno: radnja datog glagola obavlja se unutar samih njenih konstituenata, nezavisno od volje subjekta niti on za događaj snosi ikakvu odgovornost. Subjekat samo prima uticaj rezultata obavljene radnje. Događaj izražen glavnim glagolom sam po sebi je neutralan, ali kada se izrazi indirektnim pasivom, pridružuje mu se značenje štete.

Kognitivno značenje aktivne i rečenice direktnog pasiva je isto, kako tvrdi Okucu (1983: 70), osim što se razlikuju u tački gledišta: agens i pacijens zadržavaju svoja semantička svojstva, dok se razlikuju jedino njihove sintaksičke pozicije i oblik glagola. Upotreba direktnog pasiva, dakle, objašnjava se principom perspektivizacije tačke gledišta. Pod tim pojmom podrazumeva se govornikova odluka da o događaju saopštava stavljajući se u poziciju agensa ili pacijensa. 
Ovde se javlja potreba da se dodatno objasne razlozi zbog kojih japanski govornik menja perspektivu i bira pasivnu strukturu umesto aktivne. Stoga ćemo se osvrnuti na vanlingvističke i na lingvističke faktore.

Vanlingvistički faktori se još nazivaju i psihološkim. Govornik uzima tačku gledišta učesnika koji za njega ima veći psihološki značaj. Pozivajući se na tzv. „,hijerarhiji tačke gledišta” i ideju empatije, čiji je tvorac začetnik funkcionalne gramatike Kuno (1978), Okutsu (1983: 72) razvija dalje ovu teoriju, tvrdeći da je izbor tačke gledišta određen hijerarhijom imenskih reči, i daje šematski prikaz hijerarhije imenskih reči, u kojoj su članovi prikazani po principu binarne opozicije, gde je onaj na levoj strani u hijerarhiji viši: (živo /+/) > (živo /-/); (ljudsko /+/)> (ljudsko /-/); (govornik /+/)> (govornik /-/); (sagovornik /+/) > (sagovornik /-/); (pripadnik grupe /+/) $>$ (pripadnik grupe /-/). Kada na izbor tačke gledišta sa koje će govornik saopštiti o događaju utiču vanlingvistički ili psihološki faktori, to se u lingvistici naziva diskursom nemotivisana perspektivizacija.'

Na izbor tačke gledišta utiču i lingvistički faktori. Psihološki značaj nekog entiteta „može biti određen i time da li on već postoji u tzv. 'univerzumu diskursa"“ (Lyons 1977: 508). To se u lingvistici naziva diskursom uslovljena perspektivizacija. ${ }^{2}$ Govoreći o komunikativnoj funkciji rečenice i sintaksičko-semantičkoj strukturi rečenice, Murakami (1986:30) naglašava postojanje dva mehanizmima, a to su uticaj „teme u okviru datog konteksta“ što nazva još i „,spoljašnjom strukturom“(,struktura celine“), i uticaj „,unutrašnje strukture rečenice“. I Okutsu (1983: 78) tvrdi da „struktura teksta (bunsho kōsē) utiče na izbor tačke gledanja“. Pod tekstom se ovde misli na nadrečeničnu strukturu ili diskurs, kao i na strukturu same rečenice. To objašnjava „pravilom utvrđene tačke gledišta“ (shiten kotē no gensoku), po kojem „tok diskursa određuje tačku gledišta a jednom uspostavljen subjekat ne menja se usput ukoliko to nije neophodno" (Okutsu 1983: 78). Ukoliko je neki entitet bio tema (subjekat) u dotadašnjem toku diskursa, rečenica u kojoj je taj entitet predmet radnje (direktni objekat) biće transformisana u pasivnu, a radnja se saopštava u izmenjenoj perspektivi, sa predmetom radnje kao subjektom. Na nivou rečenice, ovo pravilo se ispoljava kroz ujednačavanje subjekta unutar složene rečenice. Kada se dva (ili više) povezana događaja opisuju jednom, složenom rečenicom, pravilo je da se za subjekat uzme zajednički konstituent oba događaja. Ukoliko je subjekat jednog događaja istovremeno predmet radnje drugog događaja, drugi događaj se takođe opisuje sa tačke gledišta datog subjekta tako što se umesto aktivne rečenice bira pasivna.

Ponuđeni teorijski okvir naglašava komunikativno polazište.

1 Termin prema M. Ivić. Up. Ivić 1976: 42.

2 Termin prema M. Ivić. Up. Ivić 1976: 41. 


\section{PASIVNA REČENICA U UDŽBENICIMA JAPANSKOG JEZIKA ZA POČETNI NIVO}

Ovde je dat kratak opis načina na koji je pasivna rečenica predstavljena u udžbenicima za početni nivo Nihongo shoho (1981) i Shokyū nihongo (Tokyo Gaikokugo Daigaku 1990) koji su se do sada koristili u nastavi na Filološkom fakultetu u Beogradu. Svrha ovakve analize nije da objasni kakva je praksa prikazivanja japanske pasivne rečenice u udžbenicima za početni nivo za strance u svetu ili u Srbiji, već je namera da pokaže kakvu sliku učenik stiče o ovoj jezičkoj pojavi na osnovu ova dva konkretna udžbenika koja su se do sad koristila u nastavi japanskog jezika kao glavnog na početnom nivou na Filološkom fakultetu, budući da se na višim nivoima, u udžbeniku Chūkyū nihongo (Tokyo Gaikokugo Daigaku 1994) u okviru gradiva predviđenog nastavnim planom, pasiv ponovo ne obrađuje sistematično niti se dublje analizira. ${ }^{3}$

U udžbeniku Nihongo shoho (1981), koji se ranije koristio u nastavi na Filološkom fakultetu, pasiv je predstavljen kroz sedam grupa rečeničnih tipova, koje su ovde prikazane: ${ }^{4}$

先生は太郎をしかった。

Sensē-wa Tarō-wo shikatta. Profesor je izgrdio Taroa.

太郎は次郎をなぐつた。

Tarō-wa Đirō-wo nagutta.

Taro je udario Điroa.

強盗が子供をころした。

Gōtō-ga kodomo-wo koroshita. Zločinac je ubio dete.

後ろの人が私をおした。

Ushiro-no hito-ga watashi-wo oshita Čovek iza mene me je gurnuo.
太郎は先生にしかられた。

Tarō-wa sensē-ni shikarareta.

Taro je izgrđen od strane profesora.

次郎は太郎になぐられた。

Đirō-wa Tarō-ni nagurareta.

Điro je udaren od strane Taroa.

子供が強盗にころされた。

Kodomo-wa gōtō-ni korosareta.

Dete je ubijeno od strane zločinca.

私は後ろの人におされた。

Watashi-wa ushirono hito-ni osareta..

Ja sam gurnut od strane čoveka iza mene.

3 Na Filološkom fakultetu udžbenik Chūkyū nihongo koristi se na III godini (lekcije 1-11) i na IV godini (lekcije 12-18). Pasiv se u okviru gradiva obrađuje samo kao deo šire strukture, a ne kao zasebna tema, i to: u 5 . lekciji u okviru strukture „N-ni yotte (V-rareru)“; u 7. lekciji u okviru kauzativno-pasivne strukture „V-sareru / V-serareru“; u 13. lekciji u okviru strukture „-to kangaerarete iru“; u 14. lekciji u okviru strukture „N-wa N-ni kagiru / kagirarete iru“.

4 Nihongo shoho 1981: 264-266. Rečenice su u udžbeniku pisane formalnim stilom (masu/desu), dok su, zarad ekonomičnosti, za potrebe prikazivanja u ovom radu one preinačene u neformalni oblik. 
II

巡査は泥棒を捕まえた。

Junsa-wa dorobō-wo tsukamaeta. Policajac je uhvatio lopova.

先生は雪子をほめた。

Sensē-wa Yukiko-wo hometa. Profesor je pohvalio Jukiko.
泥棒は巡査に捕まえられた。

Dorobō-wa junsa-ni tsukamaerareta. Lopov je uhvaćen od strane policajca.

雪子は先生にほめられた。

Yukiko-wa sensē-ni homerareta. Jukiko je pohvaljena od strane profesora.

III

田中は私たちを招待した。

Tanaka-wa watashitachi-wo shōtai shita.

Tanaka nas je pozvao.
私たちは田中に招待された。

Watashitachi-wa Tanaka-ni shōtai sareta.

Mi smo pozvani od strane Tanake.

\section{IV}

犬が(私の)手をかんだ。

私は犬に手をかまれた。

Inu-ga (watashi-no) te-wo kanda. Pas je ujeo (moju) ruku.

Watashi-wa inu-ni te-wo kamareta. Pas me je ujeo za ruku.

泥棒が(私の)財布を盗んだ。

Dorobō-ga (watashi-no) saifu-wo nusunda.

Lopov je ukrao (moj) novčanik.

私は泥棒に財布を盗まれた。

Watashi-wa dorobō-ni saifu-wo nusumareta.

Lopov mi je ukrao novčanik.

\section{V}

子どもになかれて,こまった。

Kodomo-ni nakarete, komatta.

Bila sam u problemu jer mi je dete plakalo.

人に来られて, 勉強ができなかった。

Hito-ni korarete, benkyō-ga dekinakatta.

Nisam mogao da učim jer mi je neko došao.

\section{VI}

この歌は世界じゅうの人にあいされている。

Kono uta-wa sekaijū-no hito-ni aisarete iru.

Ovu pesmu vole ljudi širom sveta. 


\section{VII}

\section{日本語はいちばんむずかしい言葉だと言われている。}

Nihongo-wa ichiban muzukashii kotoba da to iwarete iru.

Za japanski se kaže da je najteži jezik na svetu.

Kao što je prikazano, grupe I - IV predstavljaju parove aktivne i pasivne rečenice kojima se opisuje ista situacija. $U$ grupi II dati su primeri radnje koja obuhvata dva lica i iskazuje se prelaznim, monotranzitivnim glagolom. Primeri nisu ograničeni na negativne događaje, a pokazuju da radnja može da se iskaže i iz ugla jednog i iz ugla drugog učesnika. Grupa III opisuje odnos aktivne i pasivne rečenice koje na mesto predikata imaju glagol tipa „imenica aktivnosti + suru“. Grupa IV predstavlja situacije kod kojih je u ulozi subjekta pasivne rečenice lice-vlasnik objekta nad kojim je radnja izvršena. Taj objekat može biti deo tela ili materijalno vlasništvo osobe u ulozi subjekta. Grupa $V$ predstavlja specifičnost japanske pasivne rečenice, gde se uočava da u japanskom i neprelazni glagoli grade pasiv. I ove rečenice izražavaju negativne događaje. Lice na poziciji subjekta indirektno trpi efekat radnje. Ovaj tip pasivne rečenice nema korelativnu aktivnu rečenicu. Grupe VI i VII predstavljaju tip pasivne rečenice koji je svojstven mnogim jezicima. Grupa VI izražava situaciju kada je agens nepoznat, nevažan ili opšti, dok grupa VII izražava opšte tvrdnje ili opšte znanje, koje su uvedene pasivnim oblikom glagola iu („,rečeno je; kaže se”).

U udžbeniku Shokyū nihongo (Tokyo Gaikokugo Daigaku 1990), koji se danas koristi u nastavi na Filološkom fakultetu u Beogradu, pasiv je predstavljen kroz šest rečeničnih tipova. Prikazuje se morfološka segmentacija i morfo-sintaksička struktura rečenice, kao i njena derivacija iz korelativne aktivne rečenice. Simbolom $X$ označen je agens, simbolom Y živi pacijens (ili onaj koji „pati”) u ulozi subjekta pasivne rečenice, dok je simbolom N (noun) označen neživi objekat: ${ }^{5}$

\section{I}

Y-wa X-ni V-rareru $\quad \leftarrow \quad$ X-wa Y-wo V

マナさんは先生にしかられた。

Manasan-wa sensē-ni shikarareta.

Mana je izgrđen od strane profesora.

$\leftarrow$ 先生はマナさんをしかった。

Sensē-wa Manasan-wo shikatta.

Profesor je izgrdio Manu.

5 Tokyo Gaikokugo Daigaku 1990: 214-215. Isto kao i u slučaju primera iz prethodnog udžbenika, rečenice su ovde prikazane u neformalnom stilu. 


\section{II}

Y -wa X-ni N-wo V-rareru $\quad \leftarrow \quad$ X-wa Y-ni N-wo V 小林さんはジョンさんに仕事をたのまれた。

Kobayashi je zamoljen za posao od strane Džona.

Kobayashisan-wa Jonsan-ni shigoto-wo tanomareta.

$\leftarrow$ ジョンさんは小林さんに仕事をたのんだ。 Jonsan-wa Kobayashisan-ni shigoto-wo tanonda.

Džon je zamolio Kobajašija za posao.

\section{II}

Y-wa X-ni N-wo V-rareru $\quad \leftarrow \quad$ X-wa Y-no N-wo V 弟は兄に顔をなぐられた。

Otōto-wa ani-ni kao-wo nagurareta.

Mlađi brat je udaren u lice od strane starijeg.

$\leftarrow$ 兄は弟の顔をなぐつた。

Ani-wa otōto-ni kao-wo nagutta.

Stariji brat je udario mlađeg u lice.

\section{IV}

Y-wa X-ni Vit-rareru $\quad \leftarrow \quad$ X-ga Vit

わたしは父に死なれた。

Watashi-wa chichi-ni shinareta.

Umro mi je otac (i ja patim zbog toga).

$\leftarrow$ 父が死んだ。

Chichi-ga shinda.

Moj otac je umro.

\section{V}

N-ga X-ni V-rareru iru $\quad \leftarrow \quad$ X-wa N-wo V この歌は若い人たちに愛されている。

Kono uta-wa wakai hitotachi-ni aisarete iru.

Ovu pesmu vole mladi.

$\leftarrow$ 若い人たちはこの歌を愛している。

Wakai hitotachi-wa kono uta-wo aishite iru.

Mladi vole ovu pesmu.

\section{VI}

N-ga V-rareru $\quad \leftarrow \quad$ X-wo V

会議で予定が発表された。

Kaigi-de yotē-ga happyō sareta.

Na sastanku je objavljen novi plan. 
会議で予定を発表した。

Kaigi-de yotē-wo happyō shita.

Na sastanku su objavili novi plan.

Prema objašnjenjima, tip I grade monotranzitivni glagoli kada direktni objekat postaje subjekat, dok tip II grade ditranzitivni glagoli kada indirektni objekat postaje subjekat pasivne rečenice. Tip III izražava odnos posesije između subjekta pasivne rečenice i imenice u ulozi objekta. Objekat je obično deo tela subjekta ili nešto što subjektu pripada. Subjekat obično trpi usled radnje obavljene nad njegovim delom tela ili vlasništvom. Tip IV predstavlja pasiv smetnje ili žrtve, a grade ga i neprelazni glagoli. Radnja se odvija nezavisno od subjekta, ali subjekat indirektno trpi negativni uticaj radnje. Tipovi V i VI izražavaju situacije kada je agens opšti ili nevažan. Tip V opisuje situaciju sa uopštenim ili kolektivnim agensom, koji u rečenici biva iskazan. $U$ rečenicama tipa $\mathrm{VI}$, međutim, agens se izostavlja, jer nije bitna informacija ko je agens. Ovaj tip stavlja akcenat na to šta je izvršeno, ili ističe mesto odnosno vreme vršenja radnje.

Iz navedenog se može zaključiti da neke situacije mogu biti iskazane i aktivnom i pasivnom strukturom. Udžbenici međutim ne ukazuju na razloge za upotrebu jedne ili druge strukture. Oni stavljaju naglasak na morfo-sintaksičke promene. To jeste dovoljna informacija za ovaj nivo učenja. Ali ako se učeniku ne ponude dalja objašnjenja na višim nivoima jezičke kompetencije, o japanskoj pasivnoj rečenici on stiče nedovoljno jasnu sliku i upotreba pasiva se svodi na situacije kada je agens nepoznat, što je slično pasivu u srpskom i u drugim indoevropskim jezicima, ili, ređe, kada se govori „o nekoj neprijatnoj situaciji“.

\section{PRIMENA U UČIONICI}

Polazeći od stava da kategorija glagolskog roda nadilazi nivo rečenice i da upotrebu pasivne rečenice treba objasniti na nivou diskursa, stavljajući je u kontekst, pokušali smo da primenimo takav pristup u učionici. Održali smo specijalni čas čija tema je bila upotreba japanske pasivne rečenice na primeru rečenica iz književnog korpusa. Ciljna grupa su studenti završne godine osnovnih studija, studijski program Japanski jezik, književnost, kultura, sa 12 časova japanskog jezika nedeljno, i srednjim nivoom znanja ka višem (N3/N2). Cilj časa je osvešćivanje kod studenata razloga upotrebe pasiva u japanskom, sa posebnim naglaskom na razlike u njegovoj upotrebi u japanskom i u srpskom.

Čas traje 90 minuta i podeljen je u tri segmenta i tri oblika izvođenja: uvodni deo (10 minuta) u obliku zajedničke diskusije (Zadatak 1), teorijski deo (20 minuta) u obliku izlaganja nastavnika i praktični deo (60 minuta). Oblik rada u praktičnom delu je grupni (Zadatak 2) $\mathrm{i}$ individualni (Zadatak 3). Grupni rad je diskusija unutar grupe, a zatim razmena zapažanja 
i zaključak sa drugim grupama. Nedostatak ovakvog rada je precizan statistički podatak. Rezultati su deo rada grupe, te stoga nisu merljivi. Ipak, izabran je grupni rad, jer u grupi učesnici osećaju manji pritisak, nema brige oko toga kako će njihov individualni odgovor biti ocenjen, slobodnije razmišljaju i u razgovoru s drugim članovima grupe spoznaju ono što sami nisu uvideli. Individualni rad je samostalno rešavanje zadataka u pisanom obliku. Učestvovalo je ukupno dvadeset studenata, a grupa je bilo pet. Svi učesnici dobijaju iste zadatke. Osnovu zadataka čine tri vrste primera: 1 . tipske rečenice japanskog pasiva po ugledu na one iz udžbenika korišćenih u nastavi; 2. složeniji primeri pasivnih rečenica iz poznatih književnih dela; 3. književni prevod japanskih pasivnih rečenica iz datih dela na srpski. Korišćena su književna dela savremenih japanskih pisaca, i to ona čiji je prevod na maternji jezik dostupan. Razlog upotrebe književnog korpusa je što, za razliku od primera iz udžbenika, koji su uglavnom konstruisani za potrebe istraživanja, primeri iz književno-umetničkih dela pružaju širi okvir za kontrastivnu analizu: daju uvid u širi kontekst, rečenice su kompleksnije i na sintaksičkom i na semantičkom planu, širi je dijapazon glagolskih vremena itd. Osim toga, prema teoriji prevođenja, književni prevod „traži viši stepen ekvivalentnosti“ (Sibinović 1990: 138). Primeri iz književnog prevoda pružaju učenicima mogućnost da uvide da direktno prenošenje gramatičke strukture pasivne rečenice nije uvek dobro rešenje.

Ovde je predstavljen sadržaj časa po segmentima.

\section{Uvodni deo - diskusija}

Svrha uvodnog dela je da se studenti podsete dosada stečenog znanja o pasivnoj rečenici. Zamoljeni su da navedu razloge upotrebe pasiva u japanskom jeziku. Zatim, dobijaju zadatak da na osnovu datih rečenica razmisle zašto je u njima upotrebljen pasiv a ne aktiv, odnosno zašto je u nekima situacijama adekvatnije upotrebiti pasiv. Prevod na srpski nije ponuđen da bi studenti sami ponudili svoja rešenja.

\section{Zadatak 1}

Uporedite sledeće rečenice u aktivu i pasivu. Razmislite o razlozima upotrebe pasivne rečenice. Da li biste i vi upotrebili pasiv u opisu datih situacija?

1. マルコはミレナをふつた。(ミレナ:私の友だち）

Maruko-wa Mirena-wo futta.

$$
\Rightarrow \text { ミレナはマルコにふられた。 }
$$

Mirena-wa Maruko-ni furareta. 
2. 大学の前で女の人が私に道を聞いた。

Daigaku-no mae-de onnano hito-ga watashi-ni kiita.

$\Rightarrow$ 大学の前で女の人に道を聞かれた。

Daigaku-no mae-de onnano hito-ni michi-wo kikareta.

II

1. 先生が私をほめたので、(私は)うれしくなつた。

Sensē-ga watashi-wo hometanode, (watashi-wa) ureshiku natta.

$\Rightarrow$ 先生にほめられて、うれしくなった。

Sensē-ni homerarete, ureshiku natta.

2. 寮に帰つたとき、入口にいるおじさんが高橋を呼んだ。

Ryō-ni kaetta toki, iriguchi-ni iru ojisan-ga Takahashi-wo yonda.

$\Rightarrow$ 寮に帰つたとき、高橋は入口にいるおじさんに呼ばれた。

Ryō-ni kaetta toki, Takahashi-wa iriguchi-ni iru ojisan-ni yobareta.

3.弟とけんかをする度に、母は私たちを叱る。

Otōto-to kenka wo suru tabini, haha-wa watashitachi-wo shikaru.

）弟とけんかをする度に、母に叱られる。

Otōto-to kenka wo suru tabini, haha-ni shikareru.

4. 名前を呼んだら、返事をしてください。

Namae-wo yondara, henji-wo shite kudasai.

，名前を呼ばれたら、返事をしてください。

Namae-wo yobaretara, henji-wo shite kudasai.

III

1. 多くの国民がこの歌を知つている。

Ōku no kokumin-ga kono uta-wo shitte iru.

$\Rightarrow$ この歌は多くの国民に知られている。

Kono uta-wa ōku no kokumin-ni shirarete iru.

IV

1. その時、マリアはスカートをドアにはさまれた。

Sono toki, Maria-wa sukāto-wo doa-ni hasamareta.

2. 花子は新しいへアースタイルをほめられた。

Hanako-wa atarashii heāsutairu-wo homerareta. 


\section{Teorijski deo - izlaganje nastavnika}

Predočen je gorenavedeni teorijski okvir. Ukazano je na pasiv kao markiranu rečeničnu perspektivu. Istaknuti su lingvistički faktori koji utiču na izbor tačke gledišta, a unutar njih tok diskursa i spoljašnja struktura, struktura celine ili kontekst, i unutrašnja struktura, tj. sintaksičko-semantička struktura rečenice i ujednačavanje subjekta unutar rečenice. Navedeni su i vanlingvistički ili psihološki faktori, gde je naglašena empatija, kao i priroda i hijerarhija imenskih reči. Istaknuo je još da, prema teoriji prevođenja, „poruka u jeziku prevoda treba da ima saznajni, emocionalni i ekspresivni sadržaj po ukupnom efektu adekvatan originalu, a jezik, naročito u direktnom govoru, treba da je spontan, tečan i neusiljen" (Sibinović 1990: 138).

\section{Praktični deo}

\section{A.Rad u grupama}

Bilo je pet grupa, a svaka je imala po četiri učesnika. Učesnicima je podeljen materijal sa primerima iz poznatih književnih dela kao i književni prevod odabranih rečenica (Zadatak 2). Na prethodno usvojeno znanje o vrstama i podeli pasivnih rečenica na osnovu tipičnih primera iz udžbenika, koji se gotovo mehanički usvajaju, dodaje se nova dimenzija i produbljuje se razmišljanje o razlozima upotreba na primeru rečenica koje prezentuju širi dijapazon životnih situacija. Učesnici, svaki na svom papiru, kratko beleže odgovore na pitanja postavljena u zadatku, i papire na kraju časa predaju nastavniku radi dalje analize. Učesnici su podstaknuti da slobodno razgovaraju unutar grupe, da iznose svoja mišljenja i obrazlože odgovore za koje su se opredelili. Cilj ovog dela časa bio je da se aktivira, osvesti ili stekne znanje o razlozima upotrebe pasiva u japanskom, u rasterećenoj atmosferi, kroz diskusiju, najpre unutar grupe, a zatim i zajedno sa ostalim grupama. Posle obavljenog zadatka predstavnik grupe usmeno saopštava zaključke pred svim grupama.

\section{Zadatak 2}

Da li ste već čitali romane Sputnik ljubav Harukija Murakamija i Duša Nacume Sosekija? Sećate li se sižea, glavnih junaka? Rečenice pred vama uzete su iz ovih romana i njihovih prevoda na srpski.

Uočite glagol u pasivnom obliku. Uočite kako se data pasivna konstrukcija realizuje u srpskom prevodu. Razmislite da li bi i u srpskoj rečenici moglo da se prevede pasivnom konstrukcijom tamo gde to nije učinjeno. Kako bi to zvučalo? Obratite pažnju na rečenice gde to NE bi bilo moguće. A zašto je u japanskom upotrebljen pasiv? Navedite moguće razloge. Kojim tipovima pasivne rečenice bi odgovarali dati primeri? 
ヴェネチアでヴィヴァルディのフェスティヴァルが開かれているので、そこに も行ってみようかと思う話になっています。(Murakami 2001: 115)

Venechia de Vivarudi no fesutivaru ga hirakarete iru node, soko ni mo itte miyō ka to iu hanashi ni natte imasu.

Pošto se sada u Veneciji održava Vivaldijev festival, razmišljam da odemo tamo. (Murakami 2004: 78)

2

両親に文句を言われたくなかつたから、義務的に授業に出て、最低限の予 習と復習をこなしていただけだ。(Murakami 2001: 87)

Ryōshin ni monku wo iwaretakunakatta kara, gimutekini jugyōni dete, saitēgen no yoshū to fukushū wo konashite ita dake da.

Kako nisam želeo da mi roditelji prigovaraju, išao sam u školu iz čiste obaveze... (Murakami 2004: 60)

3

無理にして見舞いに来られたりすると、かえってこっちが心配だから。(Sōseki 1965: 433)

Murini shite mimaini koraretari suruto, kaette kocchiga shimpaidakara.

Samo bih brinuo da je silom došla da me poseti. (Soseki 2003:127)

\section{4}

事情は説明できないけれど、悪い人たちに追われているの。 (Murakami 2001: 50)

Jijōwa setsumē dekinai keredo, warui hitotachi ni owarete iru no.

Ne mogu sada da ti objašnjavam, ali jure me neki opaki ljudi. (Murakami 2004: 36)

\section{5}

ミュウに髪を触られた瞬間、(ほとんど反射的といってもいいくらい素早く、) すみれは恋に落ちた。(Murakami 2001: 15)

Myū ni kami wo sawarareta shunkan, (hotondo hanshateki to ittemo ii kurai subayaku,) Sumire wa koi ni ochita.

Istog trenutka kad joj je Mju dodirnula kosu, (gotovo brzinom refleksa) Sumire se zaljubila. (Murakami 2004: 14) (Sumire je glavna junakinja romana.) 
6

私はその人から丁寧に先生の出先を教えられた。(Sōseki 1965: 369)

Watashi wa sono hito kara tēnē ni sensē no desaki wo oshierareta.

Ona mi je ljubazno objasnila gde se Učitelj nalazi. (Soseki 2003: 32)

7

音楽大学に進み、高名なピアニストの指導を受け、その後推薦されてフラ ンスの音楽院に留学した。(Murakami 2001: 74)

Ongakudaigaku ni susumi, kōmēna pianisuto no shidō wo uke, sonoato suisen sarete Furansu no ongakuin ni ryūgaku shita.

Upisala se na muzičku akademiju i učila kod eminentnih pijanista, posle čega je uz preporuku otišla da uči na muzičkom konzervatorijumu u Francuskoj. (Murakami 2004: 52)

B.Individualni rad

Učesnicima je podeljen materijal koje čine rečenice za prevod sa srpskog na japanski, takođe primeri iz prevedenih književnih dela (Zadatak 3). Data su značenja reči koje je nastavnik smatrao nepoznatim, uz mogućnost da se učesnici konsultuju, uzajamno, s nastavnikom ili gledanjem u rečnik, ukoliko ima i drugih nepoznatih reči. Učesnici samostalno prevode rečenice pismeno i saopštavaju svoje rezultate. Na kraju časa nastavnik sakuplja pisane odgovore radi kasnije analize rezultata.

\section{Zadatak 3}

Hajde da probamo da prevedemo na japanski!

1. Zatvorena sam u kabini velikog panorama točka u zabavnom parku.

2. (Murakami 2004:151)

3. Smatralo se da kapije imaju veliko značenje. (Murakami 2004: 21)

4. Bilo bi mi teže da tako mislite o meni nego da mi odseku ruku.

5. (Soseki 2003: 61)

6. Mju je zabranjivala pušenje u kancelariji, i mrzela je kada ljudi pred njom puše. (Murakami 2004: 53)

7. Ta tajna će čoveku zauvek stezati srce. (Murakami 2004: 143)

Nepoznate reči:

zabavni park 遊園地 (yūenchi)

panorama točak 観覧車 (kanransha)

zatvoriti 閉じ込める_(tojikomeru)

odseći ruku (fig.) 身を切る (mi wo kiru)

zabraniti pušenje (u nekom prostoru) -を禁煙にする (-wo kin’en ni suru)

stezati srce 心を縛る (kokoro wo shibaru) 


\section{REZULTATI}

\section{Rezultati uvodne diskusije}

$\mathrm{U}$ odgovorima na pitanje o razlozima upotrebe pasiva u japanskom jeziku studenti navode opšta pravila o nepoznatom, uopštenom ili nevažnom agensu, koja su slična pravilima o upotrebi pasiva u njihovom maternjem jeziku i drugim jezicima koje poznaju, i koja bi se mogla podvesti pod jezičke univerzalije. Kao specifičnost japanskog jezika izdvajaju pasiv smetnje ili štete.

U podeljenom materijalu, I grupu čine rečenice direktnog pasiva (pasiva predmeta radnje i pasiva primaoca radnje). Rečenice II grupe pokazuju ujednačavanje subjekta unutar složene rečenice. III grupa predstavlja pasiv s kolektivnim agensom i IV prikazuje rečenice pasiva posesije.

Kada prevode rečenice, trude se da po svaku cenu upotrebe pasiv. Pasivnom konstrukcijom prevode rečenice iz grupa I-III, dok IV grupu ocenjuju „nezgodnom“ za to. Rezultat ovog dela je mehaničko prenošenje sintaksičke, pasivne strukture u maternji jezik, iako ona nije uobičajena i prirodna u svakodnevnoj upotrebi.

Tokom diskusije učesnici primećuju da osim pravila o „nevažnosti“ agensa, na upotrebu pasiva u nekim rečenicama utiče $i$ važnost pacijensa $i$ stavljanje pacijensa u informativni fokus rečenice (primer l/1). Prepoznaju situaciju sa kolektivnim agensom kao blisku (grupa III). Uočavaju specifičnu upotrebu tzv. pasiva posesije (grupa IV), ali tvrde da nisu sigurni da li bi se setili da ga upotrebe. Grupa II, međutim, predstavlja problem. Ne uočavaju razlog za upotrebu pasiva u rečenici, na primer Otōto-to kenka wo suru tabini, haha-ni shikareru. 'Kad god se posvađam s mlađim bratom, majka nas izgrdi.' Budući da se isto značenje u srpskom izražava aktivom, strukturom koja je identična japanskoj rečenici u aktivu Otōto-to kenka wo suru tabini, haha-wa watashitachi-wo shikaru, ovoj drugoj daju prednost. Isti odgovor daju i za ostale primere ove grupe. Ovakav odgovor je posledica interferencije maternjeg jezika, kao i nerazumevanja uticaja lingvističkih faktora na upotrebu pasiva, u ovom slučaju izbor tačke gledišta jednog subjekta i ujednačavanje subjekta u obe klauze unutar složene rečenice. 


\section{Rezultati praktičnog dela}

\section{Zadatak 2}

Učesnici ovde primećuju da se, za razliku od primera u Zadatku 1, u prevodu u većini slučajeva japanska pasivna rečenica realizuje aktivom. Uočavaju i rečenice gde bi se i u srpskom mogao upotrebiti pasiv (rečenica 1 i 7) zbog toga što agens nije iskazan, ali prevod aktivom ocenjuju kao „lepši“ ili „priodniji““

Rečenice u zadatku pokazuju sledeće tipove pasiva i razloge njegove upotrebe:

1. pasiv predmeta radnje; nepoznat ili neodređen agens:

2. pasiv primaoca; ujednačavanje subjekta unutar složene rečenice; hijerarhija imenica: ja - roditelji;

3. indirektni pasiv; smetnja; ujednačavanje subjekta unutar složene rečenice;

4. pasiv predmeta radnje; nepoznati agens; hijerarhija imenskih reči:ja - neki opaki ljudi; ujednačavanje subjekta;

5. pasiv posesije; odnos deo-celina; ujednačavanje subjekta; tok diskursa;

6. pasiv primaoca; hijerarhija imenskih reči: ja - ona;

7. pasiv predmeta; ujednačavanje subjekta.

Studenti prepoznaju sve tipove pasivnih rečenica u primerima i imenuju ih pravilno: direktni, indirektni, pasiv recipijenta, pasiv posesije. Rečenicu 1 sve grupe prepoznaju kao direktni pasiv ili pasiv predmeta radnje, i navode tačan razlog upotrebe pasiva (gore navedeno). Rečenica 2 je delom tačno interpretirana kao pasiv primaoca, a delom pogrešno - i kao idnirektni pasiv ili pasiv smetnje, $i$ to zbog negativnog značenja radnje monku-wo iu ('prigovoriti'). Samo dve grupe navode kao razlog i hijerarhiju imenskih reči. Rečenicu 3 sve grupe prepoznaju kao indirektni pasiv i navode tačan razlog upotrebe pasiva. Grupe koje su tačno prepoznale direktni pasiv ili pasiv predmeta radnje u rečenici 4 , kao razloge njegove upotrebe navodile su još i: „,naglašavanje govornika“; „govornik priča iz svog ugla“; „ovako je kraće“. Pored njih, bilo je i dve grupe koje su rečenicu 4 interpretirale kao indirektni pasiv, što govori o tendenciji da se svaka negativna radnja (ovde $o u$, 'goniti') tumači kao pasiv smetnje, tj. indirektni pasiv. Rečenicu 5 sve grupe prepoznaju kao pasiv posesije i navode tačan razlog upotrebe pasiva. Kao razlog postavljanja „vlasnika“ za temu dodaju još i empatiju govornika (onog koji o događaju saopštava) s „vlasnikom“. Rečenica 6 tačno je prepoznata kao pasiv primaoca, a kao razlog još se dodaje i to da „govornik postavlja sebe u prvi plan“ ili „u centar rečenice“. I rečenicu 7 sve grupe prepoznaju kao pasiv predmeta radnje i ispravno razumeju razlog upotrebe. 


\section{Zadatak 3}

\section{Rešenja:}

1. Zatvorena sam u kabini velikog panorama točka u zabavnom parku. (Murakami 2004:151)

遊園地の観覧車の中に閉じ込められています。(Murakami 2001: 229)

Yūenchi no kanransha no naka ni tojikomerarete imasu.

2. Smatralo se da kapije imaju veliko značenje. (Murakami 2004: 21) 門は重要な意味を持つものとして考えられていた。(Murakami 2001: 25) Mon wa jūyōna imi wo motsu mono to shite kangaerarete ita.

3. Ta tajna će čoveku zauvek stezati srce. (Murakami 2004: 143) 人はいつまでもその秘密に心を縛られ続けることになる。(Murakami 2001: 218)

Hito wa itsumademo sono himitsu ni kokoro wo shibararetsudzukeru.

4. Bilo bi mi teže da tako mislite o meni nego da mi odseku ruku. (Soseki 2003: 61)

そう思われるのは身を切られるより辛いんだから。(Sōseki 1965: 390)

Sō omowareru nowa mi wo kirareru yori tsuraindakara.

5. Mju je zabranjivala pušenje u kancelariji, i mrzela je kada ljudi pred njom puše. (Murakami 2004: 53)

ミュウはオフィスを禁煙にしていたし、自分の前でたばこを吸われることを きらった。(Murakami 2001: 76)

Myū wa ofisu wo kin'en ni shitte ita shi, jibun no mae de tabako wo suwareru koto wo kiratta.

Prvu rečenicu tačno je uradilo 19 (95\%) učesnika, drugu 17 (85\%) učesnika, treću 8 (40\%) učesnika, četvrtu 10 (50\%) učesnika i petu 11 (55\%) učesnika.

Svih 5 tačnih rečenica imalo je 5 (20\%) učesnika, 4 tačne 4 (16\%) učesnika, 3 tačne 5 (20\%) učesnika, 2 tačne 5 (20\%) učesnika, 1 tačnu 0 (o\%) učesnika i o tačnih 1 (5\%) učesnik.

Kriterijume tačnosti činili su: adekvatna upotreba pasivnog glagola na odgovarajućem mestu; pravilna upotreba pomoćnih rečci uz rečenične argumente kojim su iskazani lica i predmeti obuhvaćeni radnjom; pravilna rečenična perspektiva. Da bi se rečenica smatrala „tačno prevedenom" nije morala nužno da bude u potpunosti podudarna književnom originalu. „Tačnom“ je smatrana svaka rečenica koja je ispunjavala gorenavedene kriterijume. Prilikom vrednovanja tačnosti rečenice nije se uzimalo u obzir sledeće: glagolsko vreme, glagolski vid, upotreba 
pomoćnih rečci i drugih gramatičkih odnosno funkcionalnih reči (npr. to shite, yori, de i dr.) koje se ne tiču problema glagolskog roda, varijantnost u izboru lekseme. Odstupanja u ovim tačkama nisu diskreditovala rečenicu u pogledu tačnosti.

Rečenica 1 (Yüenchi no kanransha no naka ni tojikomerarete imasu.) je proste strukture i iskazuje radnju gde agens nije važan. Ista upotreba postoji i u srpskom, a budući da je i u srpskoj rečenici upotrebljen pasiv, bilo je očekivano da ovaj tip ne predstavlja problem u prevođenju, kao što je potvrdio i rezultat (95\% tačnih odgovora).

Slično je i u rečenici 2 (Mon wa jūyōna imi wo motsu mono to shite kangaerarete ita.), koja iskazuje situaciju sa kolektivnim agensom, a koja se u oba jezika izražava pasivom.

Rečenica 3 (Hito-wa itsumademo sono himitsu ni kokoro-wo shibarare-tsudzukeru.) izražava pasiv posesije, a na snazi je i hijerarhija između imenice za živo (hito) i neživo (himitsu). Ni jedna od ovih pojava nisu svojstvene srpskom jeziku. Budući da rečenica ima prostu strukturu s jednim predikatom, svi učesnici jesu upotrebili pasivni glagol, ali samo $40 \%$ njih je imalo potpuno tačnu rečenicu. Greške su počinjene uglavnom u upotrebi padežnih rečci (?hito-no kokoro-wa i *hito-wa kokoro-ga) ${ }^{6}$ :

$$
\text { さもないと、人の心はこの秘密に永遠にしばられる. }
$$

Rešenje hito-no kokoro-wa shibarareru gramatički može biti prihvatljivo, ali je prirodnija rečenica sa živim subjektom. Čak troje studenata je, i pored upotrebe pasivne konstrukcije, iskazalo situaciju iz perspektive neživog učesnika radnje (himitsu):

$$
\text { そうしないと、その秘密は永遠に人の心を縛られていくだろう。 }
$$

U rečenici 4 (Sō omowareru nowa mi-wo kirareru yori tsurai $n$ da kara.), prvo lice jednine je nosilac osećanja (tsurai), a istovremeno je obuhvaćeno i glagolima omou, kao predmet mišljenja, i kiru, kao vlasnik dela tela koji trpi radnju. Tu je trebalo ujednačiti subjekat $\mathrm{i}$ iskazati sve situacije iz perspektive jednog lica. Budući da su radnjom 'misliti' obuhvaćeni prvo i drugo lice jednine, usled hijerarhije imenskih reči bira se perspektiva prvog lica. Ni jedan od ova dva principa nisu svojstveni srpskom, zbog čega u dopunskoj rečenici 'da tako mislite o meni', studenti ne prepoznaju priliku za upotrebu pasiva i promenu perspektive, te umesto toga koriste aktiv (watashi-ni tsuite omou):

自分の身を切られるよりも、むしろあなたは私についてそういう風に思う なんて苦しいです。

6 Simbol * označava neadekvatno ili netačno rešenje. 
Priliku za upotrebu pasiva posesije, koji takođe ne postoji u srpskom jeziku, studenti ipak prepoznaju u dopunskoj rečenici ('da mi odseku ruku', watashi-wa mi-wo kirareru) i čak 16 (80\%) njih adekvatno upotrebljava pasivni glagol (kirareru). Greške se, međutim, javljaju u upotrebi rečci: uz imenicu vlasnika (watashi) - rečca za pripadnost *no umesto rečce za subjekat, temu ili celinu wa; uz imenicu dela tela koji mu pripada ( $m i$, 'telo', u prenesenom značenju 'ruka') - rečca za subjekat pasivne rečenice *wa ili *ga umesto rečce za pravi objekat wo, koja se u rečenicama pasiva posesije i pasiva smetnje ne menja (npr. *watashi-no mi-ga kirareru):

身が切られているより、あなたがそのように私について思っているのが苦しい。

Ovakav odgovor takođe pokazuje neprepoznavanje hijerarhije imenskih reči između imenice za živo i neživo. Od pomenutih 16 učesnika samo je 10 njih (50\% od svih učesnika) ispravno upotrebilo pasiv na oba mesta.

I rečenica 5 (Myū wa ofisu wo kin'en ni shitte ita shi, jibun no mae de tabako-wo suwareru koto wo kiratta.) je predstavljala problem zbog složene strukture. I ovde je u japanskoj rečenici na snazi hijerarhija imenskih reči (Mju, kao glavni junak, nasuprot nepoznati ljudi) kao i pravilo ujednačavanja subjekta u obe klauze. Osim toga, radnja tabako-wo suwareru može se shvatiti i kao pasiv smetnje. Ni jedna od ovih pojava nije svojstvena srpskom, te su u rečenici koju je trebalo prevesti na japanski oba predikata bila iskazana aktivom. Greške u prevodu su proizilazile iz neprepoznavanja situacije odnosno neshvatanja koji od dva predikata treba biti iskazan pasivom, kao na primer:

\section{みゆは事務所を禁煙にされ、自分の前で人々が吸うことを嫌いました。}

Osim toga, bilo je i grešaka u izboru rečce uz imenicu tabako - *ga umesto wo, što je neadekvatno, jer daje direktni pasiv:

\section{[...]、自分の前でタバコが吸われるのもいやがった。}

Ovde, međutim, postoji živi pacijens-doživljavač, koji dobija ulogu subjekta, a predmet radnje u pasivu smetnje ostaje označen rečcom wo.

Analiza prevoda pokazala je da je izuzetno visok procenat tačnosti u prevodu onih rečenica kod kojih postoji korespondencija sa upotrebom pasiva u srpskom - rečenica 1 (95\%) i rečenica 2 (85\%), dok je najmanji procenat tačnosti u prevodu rečenice 3 (40\%), koja izražava pasiv posesije, a osim toga, na snazi je i perspektivizacija iz tačke živog učesnika, uslovljena hijerarhijom imenskih reči, što je princip nepoznat u srpskom. Primeri 4 i 5, kod kojih je na snazi ujednačavanje subjekta u klauzama unutar složene rečenice i izražavanje jedne od dveju radnji pasivom, pokazuju zadovoljavajući procenat tačnosti (redom 50\% i 55\%), s tim što je procenat adekvatne upotrebe pasivnog glagola kod prve od dveju znatno 
viši (čak 80\%), dok greške postoje u upotrebi rečci. U ove dve rečenice izraženi su pasiv posesije i pasiv smetnje, što govori o tome da studenti u dovoljnom broju prepoznaju ta značenja i da pravilno produkuju rečenicu na japanskom, čak i kad su ona izražena aktivom u srpskom.

\section{ZAKLJUČAK}

Budući da pasivna rečenica u japanskom jeziku nailazi na teškoće u usvajanju i praktičnoj upotrebi za učenike čiji maternji jezik ne poznaje specifičnosti u značenjima i upotrebi karakterističnim za japansku pasivnu rečenicu, pokazuje se potreba za njenim obnavljanjem i dodatnim objašnjenjima koja se tiču razloga upotrebe pasiva. Ranija praksa koja se svodila na prevod nepovezanih rečenica sa ciljnog jezika na maternji jezik i obrnuto, ograničavajući se samo na tipske primere, rezultirala je mehaničkim prenošenjem pasivne strukture, onda kada je to moguće, ili memorisanjem jednog ograničenog broja tipičnih situacija koje u japanskom jeziku nose upotrebu pasiva, dok se u maternjem jeziku one realizuju aktivom, kao što je slučaj sa pasivom smetnje ili pasivom posesije.

Jedan od načina da se ovaj problem prevaziđe je da se pasiv objasni izborom tačke gledišta, što je stvar glagolskog roda, i stavljanjem pasiva u nadrečenični kontekst ili diskurs. Objašnjenjem pasiva sa ovog polazišta mogao bi se donekle rasvetliti problem praktične upotrebe pasivne rečenice. Uz to, mogli bi se prevazići i neki problemi u prevođenju.

To su pokazali i ovde prikazani zadaci. U prvom zadatku studenti prevode tako što, tamo gde je to moguće, mehanički prenose pasivnu strukturu iz japanskog u srpski. Uočavaju specifične rečenice pasiva posesije i pasiva smetnje, ali tvrde da nisu sigurni da li bi se setili da ga sami upotrebe. Ne uspevaju da prepoznaju razlog za upotrebu pasiva u složenoj rečenici gde je na snazi ujednačavanje subjekta unutar klauza, jer bi se isto značenje u srpskom izrazilo aktivnom strukturom, kojoj daju prednost. $U$ drugom zadatku uočavaju razliku u učestalosti u upotrebi pasiva u dva jezika, što im ukazuje na to da direktni prevod gramatičkih struktura nije uvek dobro rešenje. Iako razlikuju skoro sva značenja pasiva, još uvek ne prepoznaju razloge za upotrebu. Kroz ovaj zadatak više puta im je pružena prilika da se podsete tih razloga, te postepeno osvešćuju taj segment. Kao posledica toga, u trećem zadatku, prilično visok procenat učesnika ispravno prevodi rečenice različitih tipova, koristeći adekvatno pasiv tamo gde bi se ranije očekivala upotreba aktiva, naročito u rečenicama sa složenom strukturom.

Jedan specijalni čas nije dovoljan da se pokaže efikasnost metoda, ali odgovori učesnika tokom diskusije i u pisanoj formi pokazali su određeni pomak: od direktnog prenošenja gramatičke strukture iz jednog jezika u drugi ka aktivnom razmišljanju i osvešćivanju razloga upotrebe, što 
je donelo rezultate u prevođenju pasivnih rečenica, kakvih ranije nije bilo. Rezultati ovog rada ukazuju na to da bi ovakav pristup mogao da omogući studentu da razume i da samostalno proizvodi ne samo tipične pasivne rečenice već i one složenije. Zadaci predloženi u radu mogli bi se upotrebiti i za druge jezike u paru s japanskim i koristiti šire za rasvetljavanje fenomena pasiva studentima i nastavnicima japanskog jezika iz perspektive tačke gledišta i diskursa.

\section{REFERENCES}

\section{HAYATSU 2000}

Emiko Hayatsu, „Gendai nihongo no voisu wo megutte“, Nihongogaku Vol.19-5 (april), Tokio, 2000, 16-27.

\section{IORI 2001}

Isao lori i dr., Chū, jōkyū wo oshieru hito no tame no nihongobumpō handobukku, Tokyo, 3A, 2001.

\section{ISAKA 1997}

Jun’ichi Isaka, Koko kara hajimaru nihongogaku, Tokyo, 1997.

IVIĆ 1983

Milka Ivić, „Lingvističke konsekvence različitog pristupa odnosu 'deo-celina'“, Lingvistički ogledi, Beograd, Prosveta, 1983.

IVIĆ 1995

Milka Ivić, „O nekim gramatičkim fenomenima uslovljenim empatijom“, O zelenom konju: Novi lingvistički ogledi, Beograd, Slovograf, 1995, 206-216.

IVIĆ 1976

Milka Ivić, „Problem perspektivizacije u sintaksi“, Južnoslovenski filolog, Beograd, 1976, 29-46.

KOIZUMI 1993

Tamotsu Koizumi, Nihongo kyōshi no tame no gengogaku nyūmon, Tokyo, Taishukan, 1993.

\section{KUDŌ 1990}

Mayumi Kudō, „Gendai nihongo no judōbun“, Kotoba no kagaku 4, Tokyo, Mugishobō, 1990, 47-102.

\section{KUDŌ 1999}

Mayumi Kudō, „Gendai nihongono tensu, asupekuto, voisu ni tsuite sōgōteki kenkyū", 1998-99 nendo kagakukenkyū hōkoku, Ippankenkyū (B) kadai, No.63450058, 1999, 5-39.

KUNO 1978

Susumu Kuno, Danwa no bumpō, Tokyo, Taishukan, 1978. 


\section{LYONS 1977}

John Lyons, Semantics, Vol.2, Cambridge University Press, 1977.

\section{MIZUTANI 1985}

Nobuko Mizutani, Nichiēhikaku: Hanashikotoba no bumpō, Tokyo, Kuroshio, 1985.

\section{MORITA 1971}

Yoshiyuki Morita, „Ukemi-shieki no iikata“, Kōza Nihongo kyōiku 9, Tokyo, Waseda Daigaku Gogaku Kenkyūjō, 1971.

\section{MORITA 1994}

Yoshiyuki Morita, Kiso nihongo jiten, Tokio, 1994.

\section{MURAKAMI 2001}

Haruki Murakami, Supūtonikuno koibito, Tokio, Kōdansha, 2001.

\section{MURAKAMI 2004}

Haruki Murakami, Sputnik ljubav, Beograd, Geopoetika, 2004.

\section{MURAKAMI 1986}

San'ju Murakami, „Ukemi kōzō no bun“, Gengogaku kenkyū, Tokyo, 1986.

\section{NITTA 1991}

Yoshio Nitta, „Voisuteki hyōgen to jikosēgyōsē“, Nihongo no voisu to tahōsē, Tokyo, Kuroshio shuppan, 1991, 31-57.

\section{OKUTSU 1984}

Kēichiro Okutsu, „Bun no kumitate: SOV-kōzō to tachiba“, Nigongono hataraki (Kōza: Nigongono hyōgen), 1984, 192-222.

\section{OKUTSU 1984}

Kēichiro Okutsu, „Henkē bumpō - sēsē bumpō“, Kenkyū shiryō nihon bumpō, Vol.8, Eds. K.Kazuki - O.Hayashi, Tokyo, 1984.

\section{OKUTSU 1983}

Kēichiro Okutsu, „Naze ukemi ka? - 'shiten' kara no kēsu sutadi“, Gengogaku, Tokyo Gaikokugo Daigaku, 1983, 65-80.

\section{OKUTSU 1985}

Kēichiro Okutsu, „Nihongo to Ëgo no Ukemibun: 'Akachan' no bunseki“, Nihongogaku Vol.4, 1985, 105-115.

SIBINOVIĆ 1990

Miodrag Sibinović, Novi original - uvod u prevođenje, Beograd, 1990. 


\section{SUNAGAWA 1998}

Yuriko Sunagawa et al., Kyōshi to gakushūsha no tame no nihongo bunkēe jiten, Tokyo, Kuroshio, 1998.

\section{SHIGEMORI BUČAR 2007}

Chikako Shigemori Bučar, Voice in Contrast - Japanese and Slovene (Protivstava glagolskega načina v japonščini i slovenščini), Ljubljana, Filozofska Fakulteta, 2007.

\section{SUZUKI 1972}

Shigeyuki Suzuki, Nihongobumpō - kētairon, Kyōiku bunko 3, Tokio, Mugishobō, 1972.

\section{SUZUKI - KAWASE 1981}

Shinobu Suzuki - Ikuo Kawase, Nihongo shoho, The Japan Foundation Japanese Language Institute, 1981.

\section{SŌSEKI 1965}

Natsume Sōseki, Kokoro, Nihonno bungaku 13, Tokio, 1965.

\section{SOSEKI 2003}

Nacume Soseki, Duša, Sombor, Publikum, 2003.

\section{TAKAHASHI 2005}

Tarō Takahashi, Nihongo no bumpō, Tokyo, 2005.

\section{TERAMURA 1982}

Hideo Teramura, Nihongo no shintakusu to imi I, Tokyo, 1982.

\section{TOKYO GAIKOKUGO DAIGAKU 1990}

Tōkyō Gaikokugo Daigaku Ryūgakusē Nihongo Kyōiku Senta, Tōkyō, Shokyū Nihongo, Bonjinsha, 1990.

\section{SUMMARY}

\section{Teaching Japanese passive sentences at the beginner level with an attempt to overcome problems in their usage}

In textbooks for the beginner level which have been used in Japanese language teaching at the Faculty of Philology, University of Belgrade, passive sentences are introduced through the structures of sentence types. The conclusion is that a situation can be expressed by using either active or passive structure, but there is no further explanation for this linguistic non-economy. Consequently, we find a lack of understanding, and no use, or at least no adequate use of passive sentences at higher levels of language competence. One of the reasons for this might be interference 
of learners' mother tongue, in which the passive sentence might exist, but whose use is reduced or not widely spread. Another reason might be that the use of passive structure is defined only on the sentence level, without taking the wider context and the discourse level into the consideration. In this situation the need to explain these structures and their use within the context of the higher category arises, that is, the category of verbal voice.

The aim of this research is to examine, using the example of a special class, how students understand the use of the Japanese passive sentence when explained from the viewpoint of voice, and how such an approach can help overcome the problem of mother tongue interference in the use of the passive voice in Japanese as well as in translation from Serbian to Japanese.

In addition, some of the postulates of translation theory are pointed out in class. Afterwards, the students are assigned the task of group discussions on the use of the passive voice in the offered examples, after which they were asked to independently translate the sentences in which the passive is used in Japanese, in both directions, in written form. For those tasks we used sentences taken from the literary corpus. The instructor analyzes the collected data in the form of written translation, comparing it with a literary translation.

Keywords: voice, Japanese passive, direct passive, indirect passive, discourse, subject, perspective, point of view, empathy, hierarchy.

\section{SAŽETAK}

\section{Pasivna rečenica u nastavi japanskoga jezika na početnoj razini i nadvladavanje problema njezine uporabe}

Specifičnost japanske pasivne rečenice je u tome što u ulozi subjekta pacijensa, osim predmeta i bića izravno obuhvaćenih radnjom, to može biti i vlasnik objekta nad kojim je radnja izvršena, pa i lice koje nije obuhvaćeno glagolskom radnjom već neizravno trpi njezin utjecaj, najčešće kao smetnju. Tako pasiv obuhvaća i značenja pripadnosti i štete. U udžbenicima za početnu razinu koji su se dosad upotrebljavali u nastavi na Filološkome fakultetu u Beogradu, pasiv se u japanskome objašnjava kroz prikaz strukture i izvođenje pasivne rečenice iz aktivne. Zaključuje se da jedna situacija može biti opisana bilo aktivom bilo pasivom, ali ne daju se daljnja objašnjenja za ovu prividnu jezičnu neekonomičnost. Posljedica je nerazumijevanje i izostanak upotrebe pasivne rečenice na višim razinama jezične kompetencije. Uzrok bi ovome mogla biti interferencija materinskoga jezika, koji poseduje pasivnu strukturu, ali njezina uporaba nije široko zastupljena. Drugi bi razlog mogao biti što je uporaba pasivne rečenice 
objašnjena na razini rečenice. Otuda se javlja potreba da se ova struktura objasni na razini diskursa, u okviru šire kategorije - glagolskoga roda.

Cilj je ovoga istraživanja da se, na primjeru posebnoga sata, ispita koliko studenti razumiju upotrebu japanske pasivne rečenice kada se ona objasni s polazišta glagolskoga roda i koliko takav pristup može pomoći u nadvladavanju problema interferencije materinskoga jezika u upotrebi pasiva u japanskome, kao i u prevođenju sa srpskoga na japanski.

Osim objašnjenja o uporabi pasivne rečenice, na satu se ukazuje i na neke postulate teorije prevođenja. Zatim, studenti imaju zadatak grupno diskutirati o uporabi pasiva u ponuđenim primjerima, a potom samostalno, u pisanome obliku, u oba smjera prevesti rečenice u kojima je upotrijebljen pasiv na japanskome. Za vježbe prevođenja koristili smo se rečenicama iz književnoga korpusa. Prikupljene podatke u vidu pisanoga prijevoda nastavnik analizira, uspoređujući ih s književnim prijevodom.

Ključne riječi: glagolski rod, japanski pasiv, izravni pasiv, neizravni pasiv, diskurs, subjekt, perspektivizacija, empatija, hijerarhija. 
